\title{
A Physical Gene Map of the Bacteriophage P22 Late Region: Genetic Analysis of Cloned Fragments of P22 DNA
}

\author{
REX L. CHISHOLM, ROBERT J. DEANS, ETHEL NOLAND JACKSON, ${ }^{1}$ \\ DAVID A. JACKSON, AND JOAN E. RUTILA
}

Department of Microbiology, University of Michigan, Ann Arbor, Michigan 48109

Accepted December 21, 1979

\begin{abstract}
A physical gene map of the late region of the P22 chromosome has been constructed by genetic analysis of restriction enzyme fragments of P22 DNA cloned in a plasmid vector. Cleavage sites for restriction endonucleases $S a l I, S s t I, S m a I, X h o I$, and $B g l I$ were mapped on P22 DNA to provide physical reference points in addition to the EcoRI, HindIII, and $B a m$ HI cleavage sites previously mapped. Restriction enzymes $K p n \mathrm{I}, B g l \mathrm{II}$, and $X b a \mathrm{I}$ were found to have no cleavage sites on P22 DNA. Fragments of P22 DNA produced by cleavage with EcoRI, Bam HI, or EcoRI plus BamHI were cloned in Escherichia coli using the plasmid vector $\mathrm{pBR322}$, and the resulting recombinant plasmids were introduced into Salmonella typhimurium. The genes present on a cloned fragment were identified by the ability of the hybrid plasmid to complement or recombine with P22 amber mutations in known genes when mutant phage were used to infect $S$. typhimurium strains carrying the recombinant plasmids. These experiments place all phage genes required for $\mathbf{P 2 2}$ head morphogenesis except gene 3 on the physical map between coordinates 0.000 and 0.318 . The coding capacity of this interval is in close agreement with the molecular weights of the proteins assigned to it. The single gene for the P"Z base plate protein is placed between coordinates 0.376 and 0.420 on the physical map. These results also show that distances on the recombination frequency map are significantly distorted relative to the physical gene map of the late region. The recombination frequency map is expanded in the region of the physical gene map where terminally redundant ends of the circularly permuted mature chromosomes fall.
\end{abstract}

\section{INTRODUCTION}

A chromosome map which shows the physical location of genes on the DNA molecule is an invaluable aid to the study of genetic organization and function. However, the circularly permuted and terminally redundant form of the mature linear P22 chromosome poses some difficulties for biochemical and physical studies of P22 chromosome structure, since the ends of the molecules are not convenient physical reference points. Restriction endonuclease cleavage sites do provide physical markers independent of chromosome permutation, but construction of restriction fragment maps is complicated by the appearance of minor fragments derived from chromosome ends (Jacksonet al., 1978a). Permuted genomes also present

1 To whom reprint requests should be addressed. special problems in the isolation of specific chromosome fragments. While restriction enzyme cleavage generates specific fragments which can be separated by gel electrophoresis, preparations of such fragments are often contaminated by heterogeneoussized pieces derived from permuted chromosome ends. In addition, identification of the genes present on a particular fragment is impeded by the fact that the recombination frequency map is distorted in the region of molecular ends (Botstein et al., 1972; Jackson et al., 1978b). Thus genes cannot be assigned to restriction fragments by simply overlaying the genetic map on the physical map of restriction sites.

Our investigations of regulatory mechanisms controlling bacteriophage P22 late gene expression required construction of the P22 physical gene map presented here. 
In earlier work, cleavage sites of restriction endonucleases $E$ coRI (Jackson et al., 1978b) and HindIII (Deans and Jackson, 1979) were located to provide physical reference points on P22 DNA. The physical map was initially oriented with the recombination frequency map by use of early region substitutions or deletions which were genetically defined and could be related to the cleavage site map (Jackson et al., 1978b). Subsequently, Tn1 insertions located in late region genes 20,16 , ant, and 9 were assigned to individual $E$ coRI or Bam HI fragments (Weinstock, 1977). No substitutions, deletions or insertions in the remaining late region genes are available, and the recombination frequency map is significantly distorted with respect to gene size in this region. In order to locate late genes more precisely on the P22 physical map, we have cloned fragments of P22 DNA in the plasmid vector $\mathrm{pBR} 322$, and then have identified the genes on the cloned P22 fragments by their ability to complement or recombine with known P22 amber mutations when mutant phage are used to infect plasmid-bearing cells. These experiments have produced a physical gene map of the late region of the P22 chromosome. The physical gene map and the cloned P22 DNA fragments described here will be valuable tools in future genetic and biochemical studies of P22 gene regulation and $\mathrm{P} 22$ chromosome maturation.

\section{MATERIALS AND METHODS}

Bacterial and bacteriophage strains. P22 cI-7 obtained from $\mathrm{M}$. Levine was the source of P22 DNA for all experiments. P22 amber mutants used are from the collections of D. Botstein or M. Levine. Escherichia coli K12 strain ED8654 met $^{-} \mathrm{r}_{\mathrm{k}}{ }^{-} \mathrm{m}_{\mathrm{k}}{ }^{+}$sup EtyrTtrp $\mathrm{R}^{-}$, obtained from N. Murray, was used as the host in the cloning experiments. $E$. coli strain RR1 carrying pBR322 (Bolivar et al., 1977) was obtained from H. Boyer. Salmonella typhimurium LT2 strains DB5289 $\mathrm{r}^{-} \mathrm{m}^{-}$cys A1348am hisC527am and DB5297 $\mathrm{r}^{-} \mathrm{m}^{-}$suppE suII cysA1348am his C527am were obtained from $\mathrm{D}$. Botstein.

DNA preparations. Bacteriophage P22 DNA was prepared from virus particles as previously described (Jackson et al., 1978b).
Cells containing pBR322 (Bolivar et al., 1977) or recombinant plasmids were grown in M9-casamino acids medium (Miller, 1972) to midlog phase $\left(A_{650}=0.75-0.9\right)$, at which point chloramphenicol was added to 150 $\mu \mathrm{g} / \mathrm{ml}$ to amplify the plasmid (Clewell, 1972). Plasmid DNA was isolated from cleared lysates prepared as described by Clewell (1972) followed by phenol extraction and equilibrium centrifugation in $\mathrm{CsCl}-$ ethidium bromide density gradients. Ethidium bromide was removed by extraction with $\mathrm{NaCl}$ saturated isopropanol, and the DNA was extensively dialyzed against $10 \mathrm{~m} M$ Tris$\mathrm{HCl}, \mathrm{pH} 8.1,1 \mathrm{~m} M$ EDTA, $10 \mathrm{~m} M \mathrm{NaCl}$.

Restriction endonuclease cleavage analysis. Restriction endonuclease EcoRI was prepared according to the procedure of Thomas and Davis (1975). EcoRI digestions were carried out in $6 \mathrm{mM}$ Tris- $\mathrm{HCl}(\mathrm{pH}$ 7.4), $6 \mathrm{mM} \mathrm{MgCl}_{2}, 50 \mathrm{~m} M \mathrm{NaCl}$, and 50 $\mu \mathrm{g} / \mathrm{ml}$ gelatin. $\mathrm{Bam} \mathrm{HI}$ and $\mathrm{SalI}$ were purified by an unpublished procedure of $R$. Roberts. Bam HI cleavage reactions were performed in $6 \mathrm{mM}$ Tris- $\mathrm{HCl}(\mathrm{pH} \mathrm{7.4),6}$ $\mathrm{m} M$ 2-mercaptoethanol, $6 \mathrm{~m} M \mathrm{MgCl}_{2}$, as were $B a m \mathrm{HI} / E c o \mathrm{RI}$ double digestions. The reaction conditions for $S a l I$ cleavage were $6 \mathrm{~m} M$ Tris- $\mathrm{HCl}$ ( $\mathrm{pH} \mathrm{7.4),} 6 \mathrm{mM} \mathrm{MgCl}_{2}$, $0.2 \mathrm{~m} M$ EDTA, $150 \mathrm{mM} \mathrm{NaCl}$, and 50 $\mu \mathrm{g} / \mathrm{ml}$ gelatin. XhoI and SmaI were purchased from New England Biolabs. XhoI digestions were performed in reaction conditions described for $B a m$ HI. SmaI reaction conditions were $20 \mathrm{mM} \mathrm{KCl}, 6 \mathrm{mM}$ Tris$\mathrm{HCl}(\mathrm{pH} \mathrm{8.1}), 6 \mathrm{~m} M \mathrm{MgCl}_{2}, 6 \mathrm{mM}$ 2-mercaptoethanol, $100 \mu \mathrm{g} / \mathrm{ml}$ gelatin. $K p n \mathrm{I}$, $X b a \mathrm{I}, B g l \mathrm{I}$, and $B g l \mathrm{II}$ were purchased from Bethesda Research Laboratories and used in the reaction mixtures specified by the supplier. All reactions were incubated for $1 \mathrm{hr}$ at $37^{\circ}$, then terminated by the addition of $0.10 \mathrm{vol}$ of $25 \%$ Ficoll, $100 \mathrm{mM}$ EDTA, $2 \%$ SDS, and $0.0025 \%$ bromophenol blue. Products of the restriction reactions were analyzed by agarose and polyacrylamide gel electrophoresis as previously described (DeLeys and Jackson, 1976; Deans and Jackson, 1979). DNA in gels was visualized by staining in $1 \mu \mathrm{g} / \mathrm{ml}$ ethidium bromide for 30 min, then destaining in distilled water for $30 \mathrm{~min}$. Fragment sizes were estimated from comparisons of their electrophoretic 
mobilities with those of standard DNA molecules of known size.

Construction of hybrid plasmids. Fragments of P22 DNA produced by digestion with EcoRI, Bam HI, or Eco RI plus Bam HI were inserted into the plasmid vector $\mathrm{pBR}$ 322 (Bolivar et al., 1977) by ligation of the cohesive restriction enzyme termini. One microgram appropriately digested pBR322 DNA was mixed with a 5- to 10-fold molar excess of P22 restriction fragments in a $100-\mu \mathrm{l}$ reaction mixture consisting of $66 \mathrm{mM}$ Tris-HCl, pH 7.4, $10 \mathrm{mM} \mathrm{MgCl}_{2}, 66 \mu M$ ATP, $10 \mathrm{~m} M$ dithiothreitol, $50 \mu \mathrm{g} / \mathrm{ml}$ autoclaved gelatin. T4 polynucleotide ligase $(0.1$ unit) (purchased from Bethesda Research Laboratories) was added and the mixture incubated $4 \mathrm{hr}$ at $16^{\circ}$. In some experiments the restricted pBR322 DNA was first treated with bacterial alkaline phosphatase to prevent ligation of recircularized pBR322 molecules (Ullrich et al., 1977). DNA in 25 $\mathrm{m} M$ Tris- $\mathrm{HCl}$ ( $\mathrm{pH} 8.1$ ) was incubated at $65^{\circ}$ for $10 \mathrm{~min}$ with 0.1 units bacterial alkaline phosphatase/ $\mu \mathrm{g}$ DNA. The phosphatase reaction was terminated by phenol extraction.

Transformation of host cells. The products of the ligation reactions were introduced into $E$. coli K12 strain ED8654 by a modification of the procedure of Cameron et al. (1975). Cells were grown in L-broth (Miller, 1972) to an $A_{650}$ of 0.7 , recovered by centrifugation, and then resuspended in half the original volume of ice-cold CTG (50 $\mathrm{mM} \mathrm{CaCl}, 50 \mu \mathrm{g} / \mathrm{ml}$ thymidine, $10 \%$ glycerol). Following a 20 -min incubation on ice, cells were pelleted and resuspended in 0.05 vol cold CTG and kept on ice until used (a maximum of $24 \mathrm{hr}$ ). Recombinant plasmid DNAs were introduced into bacterial hosts by mixing $0.2 \mathrm{ml} \mathrm{CaCl}_{2}$-shocked cells and $0.1 \mathrm{ml}$ ligation mixture. This mixture was held $5 \mathrm{~min}$ on ice, incubated at $45^{\circ}$ for $2 \mathrm{~min}$, then returned to ice for an additional $5 \mathrm{~min}$. One milliliter of $\mathrm{L}$ broth was then added and the mixture incubated at $37^{\circ}$ for $45 \mathrm{~min}$ to permit expression of the plasmid encoded antibiotic resistance. Aliquots $(0.1 \mathrm{ml})$ of this culture were then plated onto tryptone plates containing $50 \mu \mathrm{g} / \mathrm{ml}$ ampicillin.

In situ colony hybridization. ${ }^{32} \mathrm{P}$-Labeled P22 DNA, prepared by nick translation
(Rigby et al., 1977) to a specific activity of 5.0 to $50 \times 10^{6} \mathrm{cpm} / \mu \mathrm{g}$, was hybridized to colonies grown on nitrocellulose disks (Schleicher and Schuell BA85) and lysed in situ as described by Grunstein and Hogness (1975), except that filters were processed by placing them on 9-cm Whatman No. 1 circles saturated with the appropriate solutions. The filters were baked at $80^{\circ}$ a minimum of $2 \mathrm{hr}$ in vacuo then incubated in $6 \times \mathrm{SSC}(1 \times \mathrm{SSC}$ is $0.15 \mathrm{M} \mathrm{NaCl}, 15 \mathrm{mM}$ sodium citrate), $0.02 \%$ polyvinyl-pyrrolidone, $0.02 \%$ Ficoll $-400,0.02 \%$ bovine serum albumin (Denhardt, 1966). Up to six filters were placed in a 9-cm petri dish and covered with $30 \mathrm{ml}$ of hybridization solution consisting of $1.5 \times 10^{5} \mathrm{cpm} /$ filter of P22 [ $\left.{ }^{32} \mathrm{P}\right]-$ DNA in $6 \times \mathrm{SSC}, 0.5 \% \mathrm{SDS}$, and $0.02 \%$ each polyvinyl-pyrrolidone, Ficoll-400, and bovine serum albumin. Mineral oil was layered on top of the hybridization solution to prevent evaporation. Hybridization was carried out for $18 \mathrm{hr}$ at $65^{\circ}$. Following hybridization, the filters were subjected to five sequential 30 -min washes with $2 \times \mathrm{SSC}$, $0.5 \%$ SDS, $10 \mathrm{~m} M$ glycine $\left(\mathrm{pH} \mathrm{9.5)}\right.$ at $65^{\circ}$. Finally, the nitro-cellulose filters were rinsed in $2 \times \mathrm{SSC}$ and air dried. Autoradiograms of the filters were prepared by exposing them to Kodak X-Omat X-ray film in Dupont Cronex intensifier screens for 18 hr at $-70^{\circ}$.

Electron microscopy. Length measurement of recombinant plasmid molecules was performed using a Zeiss EM-10A electron microscope and the aqueous procedure of Davis et al. (1979). Either SV40 form II DNA (5.22 kb; Fiers et al., 1978) or pBR322 form II dimer (8.72 kb; Sutcliffe, 1978) DNA was present in all samples as an internal length standard.

Recombination and complementation of P22 mutants with cloned fragments of P22 DNA. Plasmid DNA containing cloned P22 fragments was isolated from $E$. coli and introduced into $S$. typhimurium LT2 strain DB5289 as described above except that thymidine $(50 \mu \mathrm{g} / \mathrm{ml})$ was added to the growth medium of cultures at $A_{650}=0.3$. About $1 \mu \mathrm{g}$ plasmid DNA in $0.1 \mathrm{ml} \mathrm{0.1} M$ Tris- $\mathrm{HCl}(\mathrm{pH}$ 7.4) $50 \mu \mathrm{g} / \mathrm{ml}$ thymidine, was incubated with $0.2 \mathrm{ml}$ prepared cells, and ampicillin resistant transformants selected as described above. 
The efficiency of transformation by this procedure is much lower for S. typhimurium than for $E$. coli (Lederberg and Cohen, 1974). Only 30-60 ampicillin resistant colonies are recovered from transformation of $S$. typhimurium DB5289 by $1 \mu \mathrm{g} \mathrm{pBR322}$ DNA, while transformation of $E$. coli ED8654 by the same DNA yields $5-20 \times 10^{4}$ ampicillin resistant colonies.

$S$. typhimurium strains containing the recombinant plasmids were grown overnight in $\mathrm{L}$ broth $+50 \mu \mathrm{g} / \mathrm{ml}$ ampicillin, diluted 10-fold with fresh $\mathrm{L}$ broth and grown $2 \mathrm{hr}$ with shaking at $37^{\circ} \mathrm{C}$. These cultures were used as lawns for measuring the plating efficiency of P22 amber mutants.

To test the ability of plasmid-containing strains to complement P22 amber mutants, cultures were grown in $\mathrm{L}$ broth at $37^{\circ}$ with shaking to about $3 \times 10^{8}$ cells $/ \mathrm{ml}$, and then P22 particles were added to a multiplicity of infection of 3 phage/cell. Incubation and aeration continued at $37^{\circ}$ for $40 \mathrm{~min}$, at which point $\mathrm{CHCl}_{3}$ was added to lyse the culture. Progeny phage were titered on DB5289 $\left(\mathrm{Su}^{-}\right)$and on DB5297 $\left(\mathrm{Su}^{+}\right)$, and the burst sizes of wild-type plus amber progeny and of wild-type progeny only were calculated.

\section{RESULTS}

Location of SalI, SstI, SmaI, XhoI, and BglI Cleavage Sites in P22 DNA

The cleavage sites for several restriction enzymes which make a small number of cuts in P22 DNA have been located relative to the previously identified $E c o$ RI and $H i n d I I I$ targets in the P22 chromosome (Jackson et al., 1978b; Jackson and Deans, 1979). When P22 DNA is digested with SalI, two bands are obtained (see Fig. 1). The smaller fragment is present in low molar yield relative to the larger fragment. A similar low molar yield band present following digestion

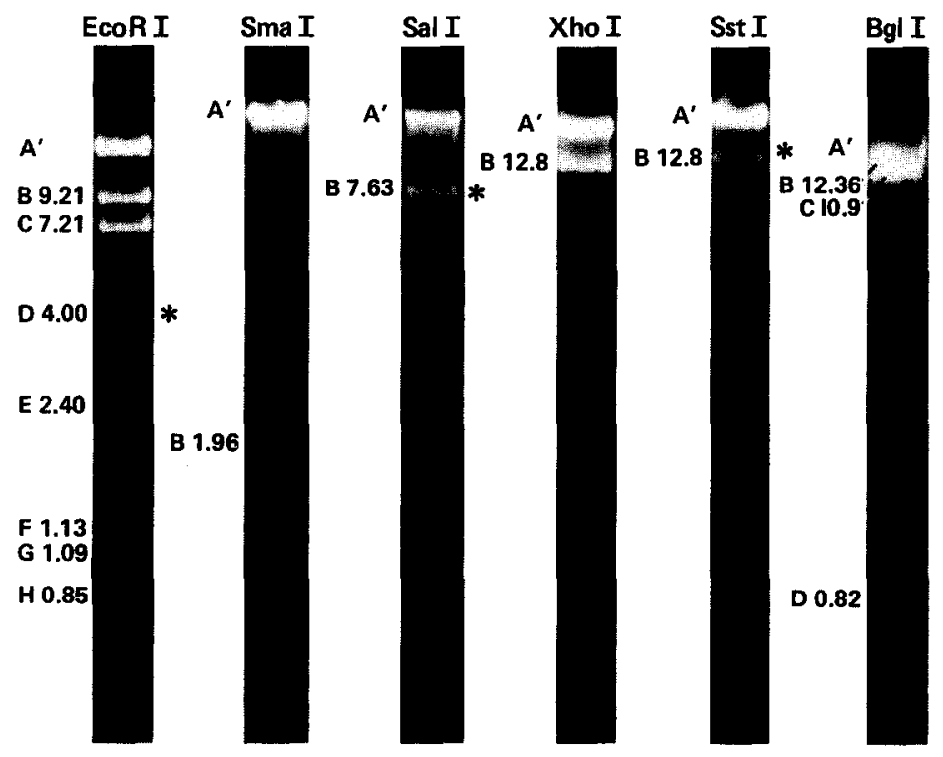

FIG. 1. Agarose gel electrophoresis of P22 DNA fragments produced by digestion with various restriction endonucleases. The letter designation for each fragment and its size (in $\mathrm{kb}$ ) determined from electrophoretic mobility is shown to the left of each track. Bands are designated by capital letters in order of increasing electrophoretic mobility. Fragments in bands marked with an asterisk are derived from a single restriction enzyme cleavage and a mature chromosome end at pac (see text for explanation). These fragments are present in less than equimolar yield (see Jackson et al. (1978) for details). Fragments labeled $A^{\prime}$ are heterogenenus shortened derivatives of intact fragments designated $\mathrm{A}$ in Fig. 2 which are produced by headful packaging. Restriction endonucleases KpnI, BglII, and $X b a \mathrm{I}$ did not cleave P22 DNA when tested in parallel with digestions of $\lambda D N A$ which produced the $\lambda$ cleavage fragments expected for each of these enzymes (gels not shown). 
of P22 DNA by $E c o$ RI has been shown to be a consequence of P22 DNA packaging (Jackson et al. 1978a). Because mature P22 DNA molecules are linear and circularly permuted, the cleavage map is circular (Jackson et al., 1978b). These mature chromosomes are generated by sequential headful packaging from a unique initiation site called pac (Jackson et al., 1978a; Tye et al., 1974). The fragment present in low molar yield in the EcoRI digest has been shown to arise from a chromosome end at pac and $E c o$ RI cleavage at the first site counterclockwise from pac (Jackson et al., 1978a). The smaller SalI fragment (SalI B) (see Fig. 1) is derived in an analogous fashion from a molecular end at pac plus a single SalI cleavage. Double digestion with $E$ coRI plus SalI generates two new fragments (3.6 and $5.6 \mathrm{~kb}$ ) which do not correspond to any $E c o$ RI or Sal I digestion product. The EcoRI $\mathrm{B}$ fragment $(9.2 \mathrm{~kb})$ is lost, while the other $E c o$ RI fragments are not cleaved by SalI. The sum of the sizes of the two new double digestion fragments equals the size of $E c o$ RI $\mathrm{B}$, indicating a single SalI site is located in $E c o$ RI B. Because the SalI B fragment represents sequences from pac counterclockwise to the $S a l I$ site, the size of $S a l \mathrm{I} \mathrm{B}$, together with the sizes of the EcoRI/SalI double digestion fragments, locate the SalI cleavage site at coordinate 0.183 on the P22 map (see Fig. 2).

Digestion of P22 DNA by $S s t I$ is analogous to SalI digestion. Two fragments, one a low molar yield packaging fragment, are produced upon Sst I digestion (see Fig. 1). EcoRI/SstI double digestion places the Sst I cleavage site in the EcoRI B fragment. As with SalI, the size of the packaging fragment $(12.8 \mathrm{~kb})$ locates the Sst I site at 0.309 P22 map units (see Fig. 2).

As shown in Fig. 1, SmaI digestion produces two fragments. SmaI A' is heterogeneous in length as a result of the counterclockwise movement of packaging cleavages relative to the genctic map, as successive terminally redundant headfuls are cut from the concatemer (Jackson et al., 1978a). SmaI B is $2.0 \mathrm{~kb}$ long. In an EcoRI/SmaI double digestion the only EcoRI fragments altered are EcoRI A and the packaging fragment $E$ coRI D (which is a seg- ment of $E \operatorname{coRI}$ A). SmaI B remains intact. Two double digestion fragments, 13.9 and $3.8 \mathrm{~kb}$, are seen. The two SmaI sites are therefore located 13.9 and $3.8 \mathrm{~kb}$ into $E c o$ RI A from the ends. Because the 4.0-kb Eco RI $\mathrm{D}$ fragment is cleaved by $S m a \mathrm{I}$, the $3.8-\mathrm{kb}$ $E$ coRI/SmaI fragment must originate at EcoRI site 1, placing SmaI site 1 at 0.005 . Therefore $S m a I$ site 2 is located at the other end of the 2.0-kb SmaI fragment at P22 map coordinate 0.958 . A packaging fragment extending from pac to SmaI site 1 should be present. However, due to the small size (less than 200 base pairs) and low yield of this fragment, it has not been detected.

$X$ ho I digestion of P22 DNA also produces two bands (Fig. 1). Again, the upper band contains fragments which are heterogeneous in length. The size of the other fragment (XhoI B) is $12.8 \mathrm{~kb}$. Upon XhoI/EcoRI double digestion only the $E$ coRI A (and the EcoRI D segment of $E c o$ RI A) are cleaved, resulting in the 12.8 -kb XhoI fragment and two double digestion products, 3.9 and $2.9 \mathrm{~kb}$ in length. Consequently the two XhoI sites are located 3.9 and $2.9 \mathrm{~kb}$ from the ends of EcoRI A which are defined by EcoRI sites 1 and 7. Placement of an XhoI cleavage site $2.9 \mathrm{~kb}$ from $E c o$ RI site 7 would cause XhoI cleavage of P22 HindIII fragment C (see Fig. 2) whereas an XhoI site at $3.9 \mathrm{~kb}$ into EcoRI A from $E c o$ RI site 7 would not. Analysis of the HindIII/XhoI double digestion products of P22 DNA indicates HindIII $\mathrm{C}$ is absent (data not shown). The two XhoI cleavage sites are thus located at map coordinates 0.002 and 0.692 , placing $X$ ho I cleavage site 1 less than 100 base pairs from pac.

Four $B g l$ I cleavage sites have been placed on the P22 chromosome by digestion of P22 DNA in combination with EcoRI, HindIII, $B a m \mathrm{HI}, X h o \mathrm{I}$, and SstI. The products of $B g l$ I cleavage of P22 DNA are shown in Fig. 1. In a $B a m \mathrm{HI} / B g l \mathrm{I}$ double digestion, the $B g l \mathrm{I}$ C fragment is lost, and the Bam HI B fragment (see Fig. 2) is intact (data not shown). Therefore, BglI C must overlap both Bam HI cleavage sites. Double digestion with HindIII places one terminus of $B g l I \mathrm{C}$ in the HindIII A fragment at coordinate 0.335 . EcoRI fragments $\mathrm{F}$ and $\mathrm{H}$ are both cleaved by $B g l \mathrm{I}$, while $E$ coRI G 


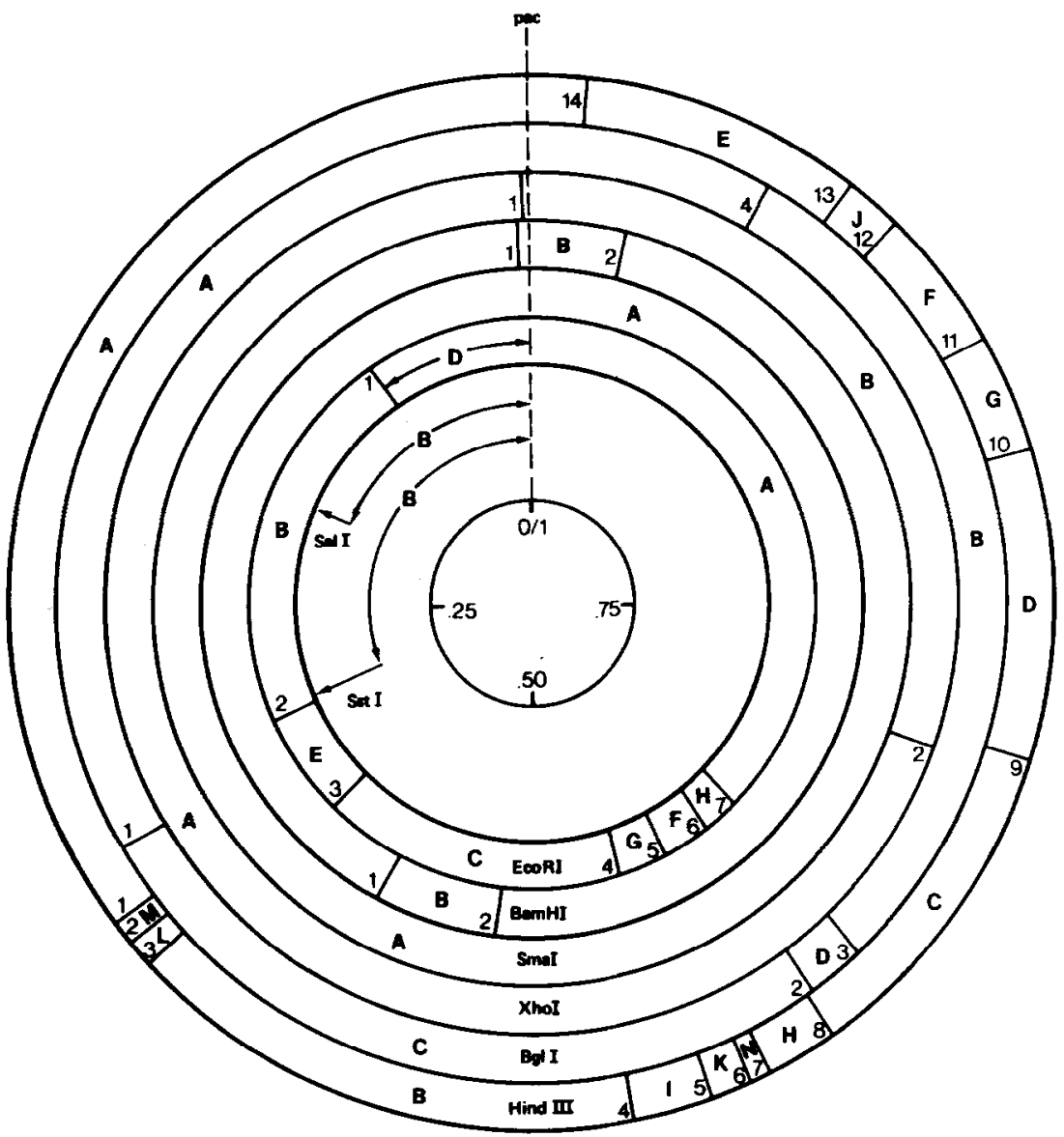

FIG. 2. Restriction endonuclease cleavage site map of P22 DNA. EcoRI, BamHI, SmaI, XhoI, $B g l \mathrm{I}$, and HindIII cleavage sites are shown to scale in six concentric rings. Positions of the single cleavage sites for SalI and SstI are indicated by arrows. $K p n I, B g l \mathrm{II}$, and $X b a \mathrm{I}$ do not cleave P22 DNA. The cleavage sites for each restriction endonuclease are numbered sequentially in a counterclockwise direction starting with the first site counterclockwise from pac. The EcoRI and HindIII cleavage site maps have been reported previously (Jackson et al., 1978b; Deans and Jackson, 1979a), except that Youderian and Susskind (manuscript in preparation) have shown that the order of HindIII fragments $\mathrm{H}$ and I were reversed and the correct order is shown here. The BamHI sites were mapped by Weinstock (1977). Physical map coordinates are fractions of the length of the P22 genome (41.6 kb; Jackson et al., 1978a). The coordinate system has been reoriented, with the origin now placed at pac. Previously the origin of the coordinate system was defined at EcoRI site 1 (Jackson et al., 1978b). The coordinates of each cleavage site are reported in Table 1.

is not. The size and map positions of these fragments (Fig. 2) demand that $B g l I$ fragment $\mathrm{D}$ must be generated by cleavage at $B g l$ I sites 2 and 3 in $E c o R I F$ and $\mathrm{H}$, respectively (Fig. 2). Map coordinates of $B g l \mathrm{I}$ site $2(0.598)$ and $B g l \mathrm{I}$ site $3(0.618)$ were determined by $B g l \mathrm{I} / \mathrm{Hind}$ III double digestion. BglI/Sst I double digestion indicates $B g l$ I A overlaps the SstI site as shown in Fig. 2 and is generated by cleavage at $B g l I$ sites 1 and 4. The exact location of $B g l I$ site $4(0.916)$ was determined from the sizes of $B g l \mathrm{I} / \mathrm{HindIII}$ double digestion products. As can be seen in Fig. 1, the BglI A' fragment appears heterogeneous and smaller in size than predicted. Since the pac site is located internal to $B g l \mathrm{I} \mathrm{A}$, this fragment is never intact, and it appears heterogeneous in size due to the varying positions of chromosome ends. 
The location of the cleavage sites of the five restriction endonucleases used here are shown in Fig. 2 in relation to the positions of Eco RI, HindIII and BamHI sites previously mapped (Jackson et al., 1978a; Deans and Jackson, 1979; Weinstock, 1977). The locations of the restriction sites displayed in Fig. 2 provide useful physical markers in all regions of the $\mathrm{P} 22$ genome, and in particular facilitate the physical subdivision of the genome as described below.

\section{Cloning of P22 EcoRI Fragments}

The utility of the physical map shown in Fig. 2 can be increased by location of specific P22 genes relative to the known restriction targets. In previous work, some early P22 genes (Jackson et al., 1978b) and genes 20, 16, ant, and 9 (Weinstock, 1977) have been located with respect to particular restriction fragments. To facilitate the ordering of additional P22 genes, and particularly late genes, with respect to the physical map, we have cloned fragments of P22 DNA produced by cleavage with $E c o \mathrm{RI}$ or Bam HI or $B a m H I$ plus $E c o$ RI. In our initial cloning experiments, unfractionated $E c o$ RI limit digest fragments of P22 DNA were inserted by ligation into the EcoRI site of the plasmid vector $\mathrm{pBR} 322$, and the products introduced into $E$. coli by transformation. Because the pBR322 vector EcoRI linear DNA was treated with bacterial alkaline phosphatase to eliminate ligation of recircularized pBR322 linears (Ullrich et al., 1977), all $\mathrm{Ap}^{\mathrm{r}}$ and $\mathrm{Tc}^{\mathrm{r}}$ clones obtained were expected to contain inserted P22 EcoRI fragments. Comparison of EcoRI digests of plasmid DNA prepared from these clones and P22 DNA allowed initial identification of the cloned $\mathrm{P} 22 \mathrm{E}$ co RI fragments. Clones pP22-1, pP22-2, pP22-3, pP22-4, pP22-6, and pP22-7 which contain P22 EcoRI fragments $\mathrm{H}, \mathrm{F}, \mathrm{D}, \mathrm{B}, \mathrm{E}$ and $\mathrm{G}$ respectively were obtained in this manner (see Figs. 3 and 4). The identity of the cloned fragments was confirmed in two ways. First, each recombinant plasmid was digested with EcoRI and the resulting fragments separated by electrophoresis in agarose, then transferred to nitrocellulose by the method of Southern (1975) and hybridized with ${ }^{32} \mathrm{P}$.
TABLE 1

Physical MaP CoORdinates of Restriction Endonuclease Cleavage Sites on P22 $\mathrm{DNA}^{a}$

\begin{tabular}{|c|c|c|c|c|c|}
\hline \multicolumn{2}{|c|}{$\begin{array}{l}\text { Restriction } \\
\text { endonuclease } \\
\text { cleavage site }\end{array}$} & \multirow{2}{*}{$\begin{array}{c}\begin{array}{c}\text { Map } \\
\text { position }\end{array} \\
0.096\end{array}$} & \multicolumn{2}{|c|}{$\begin{array}{l}\text { Restriction } \\
\text { endonuclease } \\
\text { cleavage site }\end{array}$} & \multirow{2}{*}{$\begin{array}{c}\begin{array}{c}\text { Map } \\
\text { position }\end{array} \\
0.420\end{array}$} \\
\hline$E c o$ RI & 1 & & $B a m \mathrm{HI}$ & 1 & \\
\hline & 2 & 0.318 & & 2 & 0.481 \\
\hline & 3 & 0.376 & & & \\
\hline & 4 & 0.550 & SalI & 1 & 0.183 \\
\hline & 5 & 0.576 & & & \\
\hline & 6 & 0.603 & & & \\
\hline & 7 & 0.623 & SstI & 1 & 0.309 \\
\hline \multirow[t]{14}{*}{$H i n \mathrm{dIII}$} & 1 & 0.353 & $S m a \mathrm{I}$ & 1 & 0.005 \\
\hline & 2 & 0.360 & & 2 & 0.958 \\
\hline & 3 & 0.368 & & & \\
\hline & 4 & 0.530 & & & \\
\hline & 5 & 0.554 & & & \\
\hline & 6 & 0.566 & & & \\
\hline & 7 & 0.573 & XhoI & 1 & 0.002 \\
\hline & 8 & 0.596 & & 2 & 0.692 \\
\hline & 9 & 0.699 & & & \\
\hline & 10 & 0.795 & $B g l \mathrm{I}$ & 1 & 0.335 \\
\hline & 11 & 0.832 & & 2 & 0.598 \\
\hline & 12 & 0.876 & & 3 & 0.618 \\
\hline & 13 & 0.894 & & 4 & 0.916 \\
\hline & 14 & 0.982 & & & \\
\hline
\end{tabular}

a Physical map coordinates are fractions of the P22 genome (41.6 kb; Jackson et al., 1978b). Cuordinates of $E c o$ RI cleavage sites were determined previously (Jackson et al., 1978b) but values given here reflect realignment of the coordinate system to originate at pac. HindIII site coordinates were reported previously (Deans and Jackson, 1979), and Bam HI site coordinates were calculated from the data of Weinstock and Botstein (Weinstock, 1977). Coordinates for cleavage sites for the other enzymes in the table were determined as described in the text.

labeled P22 DNA. As shown in Fig. 3, the fragments derived from the recombinant plasmids hybridize with P22 DNA and migrate at the positions characteristic of P22 EcoRI fragments, supporting the initial identification of the cloned P22 DNA fragments. Digestion with additional restriction enzymes was used to further characterize each of the recombinant plasmids. Beside providing further evidence for the identity of the cloned P22 segment, this analysis defines the orientation of the 


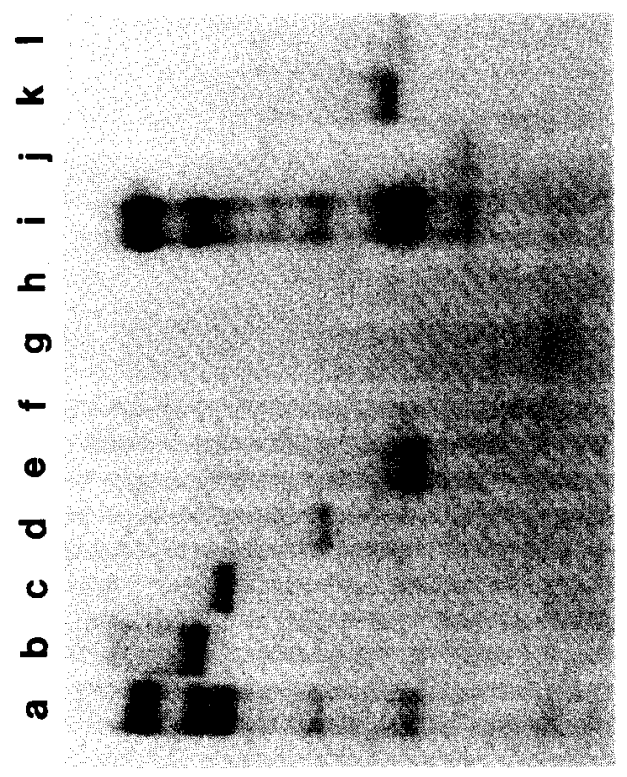

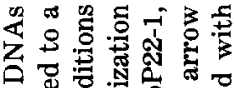

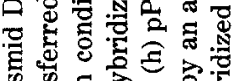

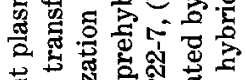

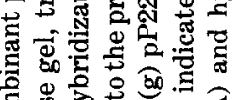

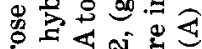

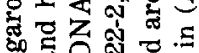
o

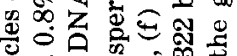

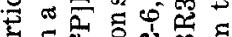

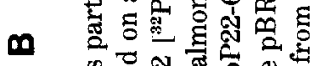

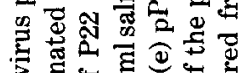
5.

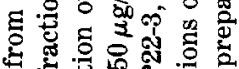
远荡 जิ

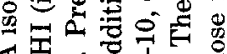
药

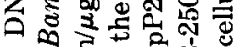

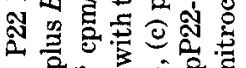

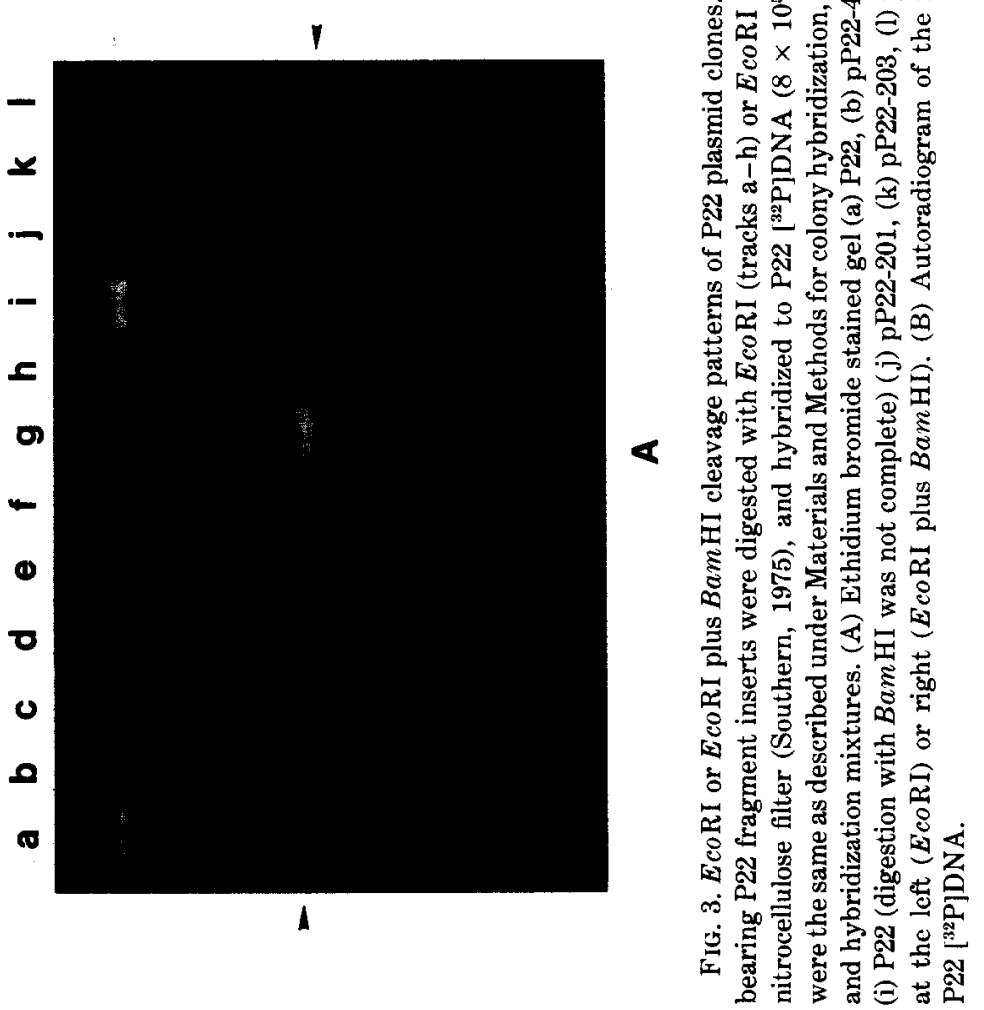




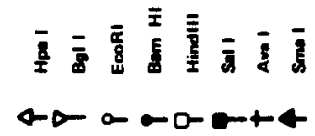

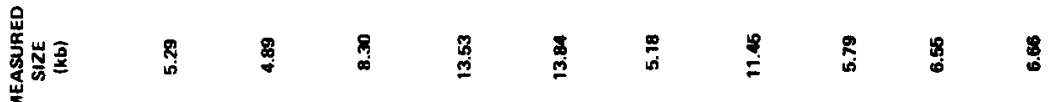

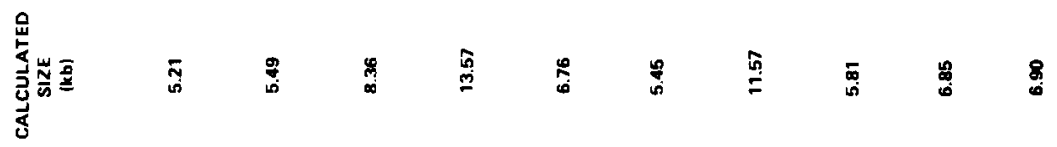

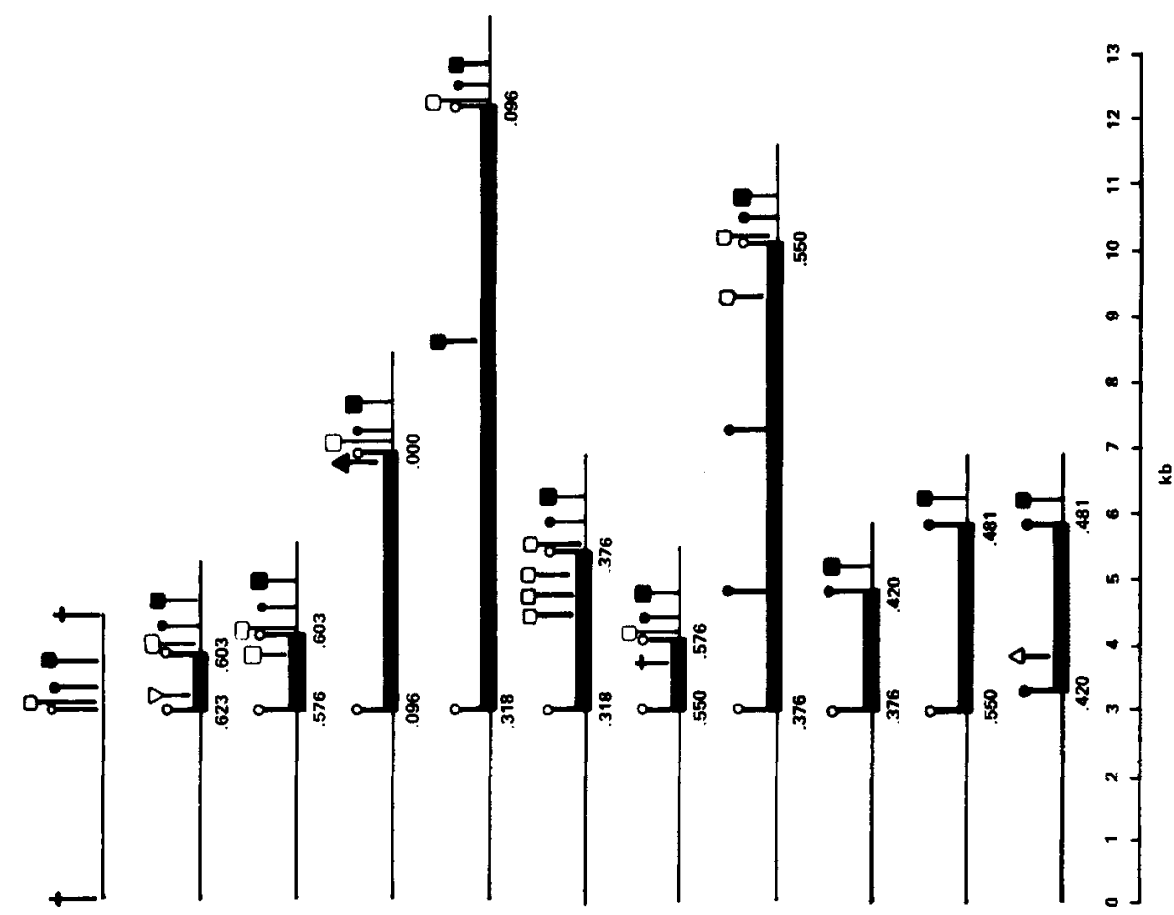

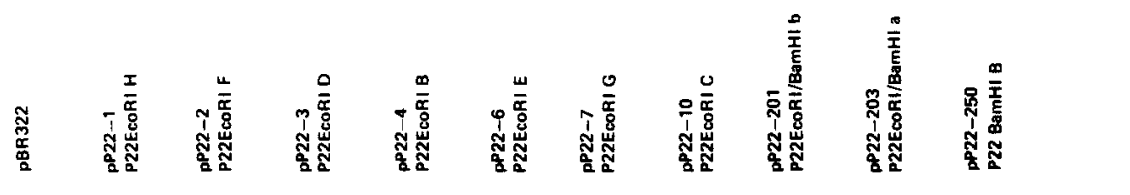

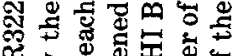

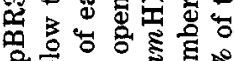

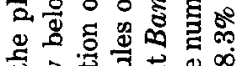

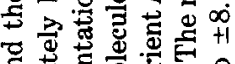
㟧 政

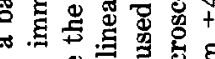
吅 동

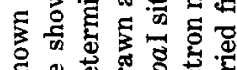

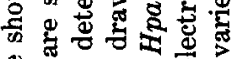

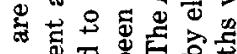

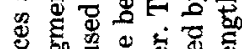
运 可

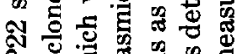

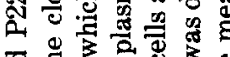
运 응 范 웡 F

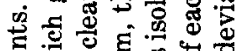
政 结

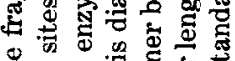
\% क ขै 议 ह d g 5

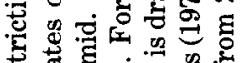
क力

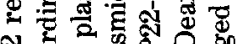
玄 so 을 的 畓

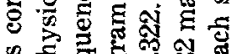
吅总

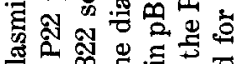
웡

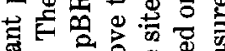

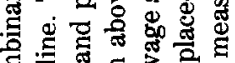
育 $\approx$ ฟิ

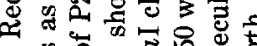

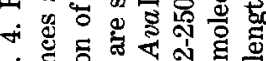

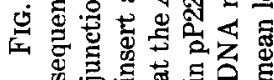


inserted P22 fragments relative to $\mathrm{pBR} 322$. Figure 4 illustrates the structure and orientation determined for each recombinant plasmid.

The contour length of each recombinant plasmid was measured by electron microscopy, and the molecular weights calculated from these results compared with the molecular weights predicted from the known sizes of the vector and inserts (Fig. 4). As can be seen from the data in Fig. 4, the calculated and measured sizes of the recombinant plasmids are in good agreement, except in the case of pP22-6, for which the calculated size is only one half that determined by electron microscopy. EcoRI digestion of pP22-6 yields only two fragments, the pBR322 EcoRI linear and the cloned P22 EcoRI E fragment. This result indicates that pP22-6 is a dimer consisting of two copies each of the pBR322 EcoRI linear and the P22 Eco RI E fragment. HindIII digestion shows this plasmid to consist of two monomeric units ( $\mathrm{pBR} 322$ linked to P22 $E c o$ RI E) in a head to tail orientation.

Neither the $E c o$ RI A nor $E c o$ RI C fragments of P22 were obtained in the shotgun experiment described above. This result may suggest that these segments of P22 encode functions lethal to the $E$. coli host. Attempts to clone these fragments from DNA enriched for these specific fragments were therefore undertaken. The P22 Eco RI $\mathrm{C}$ fragment has been cloned (J. Yoder, E. Jackson, and D. Jackson, in preparation) in a $\lambda \mathrm{gt}$ phage vector (Murray and Murray, 1974; Thomas et al., 1974). Eco RI digestion of this recombinant phage produces three fragments, only one of which-P22 EcoRI C-has two EcoRI termini. Following ligation and transformation into $E$. coli, all plasmids carrying P22 sequences should have $E c o$ RI C inserts. A 10 -fold molar excess of EcoRI digested $\lambda \mathrm{gt} \cdot \mathrm{P} 22$ EcoRI C hybrid phage was mixed with EcoRI digested pBR322, ligated, and introduced into $E$. coli. Colonies carrying P22 sequences were then identified by colony hybridization using P22 $\left.{ }^{32} \mathrm{P}\right] \mathrm{DNA}$ as the probe. A single P22 positive colony was obtained from this experiment. The plasmid obtained from these cells, pP22-10, contains an Eco RI insert which hybridizes with P22 DNA (see
Fig. 3), comigrates in gel electrophoresis with $E c o$ RI C, and yields a $B a m \mathrm{HI}$ digestion pattern indistinguishable from that of $E c o$ RI C. Because of the very low yield of plasmids containing $E c o \mathrm{RI} \mathrm{C}$ in this experiment and because of our inability to recover EcoRI C plasmids (but not plasmids containing other P22 EcoRI fragments) in other clonings from DNA fragment pools enriched for EcoRI C, there may be some question as to whether the $E c o \mathrm{RI} C$ insert in pP22-10 is the wild-type sequence.

Several attempts to clone the P22 Eco RI A fragment have been unsuccessful despite the use of DNA pools enriched for P22 $E c o$ RI A DNA. P22 DNA consisting of 65 mol\% P22 EcoRI A DNA was obtained by preparative sucrose gradient centrifugation of $E c o$ RI digested P22 DNA and ligated to $E c o$ RI digested pBR322 DNA. Since the EcoRI A fragment carries the P22 early promoters controlled by phage repressor, the ligation mixture was also introduced into an $E$. coli host (ED8654) lysogenized with a $\lambda i m m 21$ phage which encodes a repressor able to repress P22 early functions (Botstein and Herskowitz, 1974). No recombinant plasmids containing $E$ co RI A were obtained from these experiments. Other P22 EcoRI fragments, present as minor components of the enriched EcoRI A preparation, have been cloned from these pools, suggesting that a function or functions coded for by P22 EcoRI A may be lethal for the host cells, even in a $\lambda$ imm 21 lysogen.

\section{Cloning of P22 BamHI and BamHI/EcoRI Double Digestion Products}

As can be seen from Fig. 2, the EcoRI C fragment of P22 is cleaved at two sites by $B a m \mathrm{HI}$, to produce three new fragments, one having two Bam HI termini, and the other two having one $E c o$ RI terminus and one $B a m$ HI end each (Weinstock, 1977). The BamHI site in pBR322 is located in the tetracycline resistance gene, 375 bases from the EcoRI site (Sutcliffe, 1978). Insertion of a DNA fragment at the BamHI site of pBR322 therefore inactivates the tetracycline resistance phenotype. Recombinant plasmids containing either Bam $\mathrm{HI}$ or Bam$\mathrm{HI} / E c o \mathrm{RI}$ fragments can thus be readily 
TABLE 2

Plating Efficiency of P22 amber Mutants on $S$. typhimurium Su-Strains CONTAINING Cloned Fragments of P22 DNA ${ }^{a}$

\begin{tabular}{|c|c|c|c|c|c|}
\hline \multirow[b]{2}{*}{ P22 strain } & \multicolumn{5}{|c|}{$\mathrm{Su}^{-}$lawns } \\
\hline & 5289/pBR322 & $5289 / \mathrm{pP} 22-3$ & $5289 / \mathrm{pP} 22-4$ & $5289 / \mathrm{pP} 22-201$ & $5289 / \mathrm{pP} 22-250$ \\
\hline wild type & 1.0 & 1.0 & 1.0 & 1.0 & 1.0 \\
\hline $19^{-} a m \mathrm{~N} 11$ & $8.2 \times 10^{-6}$ & $10 \times 10^{-6}$ & $21 \times 10^{-6}$ & & \\
\hline 3-am H314 & $84 \times 10^{-6}$ & $4.3 \times 10^{-6}$ & $27 \times 10^{-6}$ & & \\
\hline 3-am Н317 & $21 \times 10^{-6}$ & $2.5 \times 10^{-6}$ & $7.7 \times 10^{-6}$ & & \\
\hline 2-am Н303 & $0.3 \times 10^{-6}$ & 1.1 & $0.2 \times 10^{-6}$ & & \\
\hline $1^{-} a m \mathrm{~N} 109$ & $2.6 \times 10^{-6}$ & 1.1 & $4.7 \times 10^{-6}$ & & \\
\hline $8^{-} a m \mathrm{~N} 123$ & $16 \times 10^{-6}$ & 0.044 & $76 \times 10^{-6}$ & & \\
\hline $8^{-} a m \mathrm{H} 304$ & $5.8 \times 10^{-6}$ & $7.3 \times 10^{-6}$ & 0.0019 & & \\
\hline $8^{-} a m \mathrm{H} 202$ & $1.1 \times 10^{-6}$ & $1.5 \times 10^{-6}$ & 0.0045 & & \\
\hline $8^{-} a m \mathrm{~N} 125$ & $55 \times 10^{-6}$ & $56 \times 10^{-6}$ & 0.0065 & & \\
\hline $5^{-} a m \mathrm{~N} 8$ & $24 \times 10^{-6}$ & $21 \times 10^{-6}$ & 1.1 & & \\
\hline $5^{-} a m \mathrm{~N} 114$ & $4.2 \times 10^{-6}$ & $3.6 \times 10^{-6}$ & 0.84 & & \\
\hline $5^{-} a m \mathrm{~N} 3$ & $3.1 \times 10^{-6}$ & $2.5 \times 10^{-6}$ & 0.91 & & \\
\hline $7^{-} a m \mathrm{~N} 1375$ & $15 \times 10^{-6}$ & $11 \times 10^{-6}$ & 0.1 & & \\
\hline $16^{-} a m \mathrm{~N} 121$ & $2.3 \times 10^{-6}$ & $1.4 \times 10^{-6}$ & 0.31 & & \\
\hline $9^{-} a m \mathrm{H} 1272$ & $87 \times 10^{-6}$ & & & 0.005 & $67 \times 10^{-6}$ \\
\hline 9-am H840 & $0.7 \times 10^{-6}$ & & & 0.004 & $10 \times 10^{-6}$ \\
\hline $9^{-} a m \mathrm{H} 1014$ & $0.4 \times 10^{-6}$ & & & 0.002 & $22 \times 10^{-6}$ \\
\hline
\end{tabular}

a The plating efficiency is the ratio of the titer on the plasmid-containing strain to the titer on DB5297 ( $\left.\mathrm{Su}^{+}\right)$. When several different amber alleles of a gene are used, the order in the table corresponds to the genetic map order determined by tests for recombination of the markers with prophage deletions of varying lengths within the gene. Gene 8 and gene 5 mutations were ordered by F. Winston and D. Botstein (unpublished experiments) and gene 9 mutations were ordered by P. Berget (unpublished experiments). Gene 8 amber alleles H202 and $\mathrm{N} 125$ fall in the same group. Gene $8^{-} a m \mathrm{~N} 123$ lies nearest the end of the gene encoding the amino terminus of the protein (King et al., 1978). Gene $9^{-} \mathrm{am}$ H1272 represents the promoter-proximal and $9^{-} \mathrm{am} H 1014$ the promoter-distal groups of gene 9 amber mutations (Berget, unpublished experiments).

identified by screening $\mathrm{Ap}^{\mathrm{r}}$ colonies for tetracycline sensitivity (Bolivar et al., 1977). Using this method, the Bam HI B fragment and both $B a m \mathrm{HI} / E c o \mathrm{RI}$ double digestion fragments were cloned. Figure 4 shows the characteristics of the three plasmids obtained. Plasmids pP22-201 and pP22-203 contain the large and small $B a m \mathrm{HI} / E c o \mathrm{RI}$ fragments, respectively, and $\mathrm{pP} 22-250$ contains the BamHI-B fragment. Each of these plasmids was analyzed as described above for the EcoRI inserts (see Figs. 3 and 4).

\section{Physical Location of P22 Late Genes}

Genes required for morphogenesis of the P22 particle are expected to lie from about coordinate 0.9 counterclockwise to about coordinate 0.4 of the P22 physical map
(Jackson et al., 1978b; Deans and Jackson, 1979; Weinstock, 1977). In order to define further the physical location of P22 genes in this region, we have mapped known P22 late genes to individual cloned fragments. Plasmids containing P22 DNA inserts were introduced into S. typhimurium DB5289 (see Materials and Methods). P22 amber mutants defective in known genes were then plated on these $\mathrm{Su}^{-}$strains carrying the recombinant plasmids. The P22 inserts in the plasmids were derived from wild-type DNA. Therefore recombination between an infecting amber mutant phage and the chimeric plasmid will produce phage able to grow in the $\mathrm{Su}^{-}$host if the cloned P22 DNA fragment carries the wild-type allele of the defective gene. Recombination between P22 amber mutants and cloned fragments 


\section{TABLE 3}

Burst Size of P22 Amber Mutants in $S$. typhimurium $\mathrm{Su}^{-}$Strains Carrying Cloned FRAGMENTS OF P22 WILD-TYPE DNA ${ }^{a}$

\begin{tabular}{|c|c|c|c|}
\hline \multirow[b]{2}{*}{ Host } & \multirow[b]{2}{*}{ P22 Strain } & \multicolumn{2}{|c|}{$\begin{array}{l}\text { Burst size } \\
\text { on indicator }\end{array}$} \\
\hline & & $\mathrm{Su}^{-}$ & $\mathrm{Su}^{+}$ \\
\hline 5289/pBR322 & $\begin{array}{l}\text { Wild type } \\
1^{-} a m \mathrm{~N} 109 \\
2^{-} a m \mathrm{H} 303 \\
8^{-} a m \mathrm{~N} 123 \\
8^{-} a m \mathrm{H} 202 \\
5^{-} a m \mathrm{~N} 8 \\
5^{-} a m \mathrm{~N} 114 \\
7^{-} a m \mathrm{~N} 1375 \\
16^{-} a m \mathrm{~N} 121 \\
9^{-} a m \mathrm{H} 1014\end{array}$ & $\begin{array}{l}500 \\
0.015 \\
0.018 \\
0.024 \\
0.008 \\
0.015 \\
0.0005 \\
0.031 \\
0.011 \\
0.0004\end{array}$ & $\begin{array}{l}682 \\
0.075 \\
0.056 \\
0.059 \\
0.059 \\
0.074 \\
0.006 \\
2.58 \\
0.079 \\
0.128\end{array}$ \\
\hline $\begin{array}{l}5289 / \mathrm{pP} 22-3 \\
\text { (EcoRI D) }\end{array}$ & $\begin{array}{l}\text { Wild type } \\
1^{-} a m \text { N109 } \\
2-a m \mathrm{H} 303 \\
8^{-} a m \mathrm{~N} 123\end{array}$ & $\begin{array}{r}328 \\
4.0 \\
3.7 \\
0.7\end{array}$ & $\begin{array}{l}352 \\
131 \\
122 \\
4.5\end{array}$ \\
\hline $\begin{array}{l}5289 / \mathrm{pP} 22-4 \\
(\text { Eco RI B) }\end{array}$ & $\begin{array}{l}\text { Wild type } \\
8^{-} \text {am } \mathrm{H} 202 \\
5^{-} a m \mathrm{~N} 8 \\
5 \text { am } 114 \\
7^{-} \text {am } \mathrm{N} 1375 \\
16^{-} a m \mathrm{~N} 121\end{array}$ & $\begin{array}{l}466 \\
0.13 \\
2.3 \\
0.84 \\
2.24 \\
1.89\end{array}$ & $\begin{array}{c}403 \\
0.25 \\
18.5 \\
10.1 \\
11.2 \\
14.1\end{array}$ \\
\hline $\begin{array}{l}\text { 5289/pP22-201 } \\
\quad(E \operatorname{coRI} / B a m \mathrm{HI} \text { b) }\end{array}$ & $\begin{array}{l}\text { Wild type } \\
9^{-} a m \text { H1014 }\end{array}$ & $\begin{array}{l}439 \\
0.0046\end{array}$ & $\begin{array}{l}453 \\
0.204\end{array}$ \\
\hline
\end{tabular}

${ }^{a}$ The ability of plasmid-carrying $\mathrm{Su}^{-}$strains to complement P22 amber mutations was measured as described under Materials and Methods.

should be detected by an increase in plating efficiency on the $\mathrm{Su}^{-}$host carrying the plasmid (Campbell et al., 1978). Table 2 shows that plating efficiencies of amber mutants are increased two to six orders of magnitude by the presence in the $\mathrm{Su}^{-}$host of a cloned fragment carrying the wild-type allele. The data of Table 2 indicate that P22 EcoRI fragment D (plasmid pP22-3) contains wildtype alleles of $2^{-} a m \mathrm{H} 303,1^{-} a m \mathrm{~N} 109$, and 8-amN123, while P22 EcoRI fragment B (plasmid pP22-4) carries the wild-type alleles of the other $8^{-}$amber alleles tested, as well as the $5^{-}, 7^{-}$, and $16^{-}$amber alleles used. All three $9^{-}$amber mutants plate with increased efficiency on the Su host containing plasmid pP22-201, and therefore these markers lie in the P22 Bam HI/EcoRI fragment between Bam HI site 1 and EcoRI site 3 .

Certain of the amber mutants plate on a particular plasmid-containing $\mathrm{Su}^{-}$host as effi- ciently as on the $\mathrm{Su}^{+}$host (see Table 2). Such high plating efficiency would be expected if the plasmid produced the phage protein defective in the amber mutant. To determine whether these plasmids can complement P22 amber mutants, the burst size of amber and wild-type progeny produced by infection of the plasmid-bearing $\mathrm{Su}^{-}$cell was measured (Table 3). A sizeable burst of phage which are still genetically amber indicates complementation is occurring. Table 3 shows that $p$ P22-3 provides the gene 1 and gene 2 proteins. (The efficient complementation observed is not due to production of $\mathrm{p} 2$ by the few wild-type recombinant phages produced since another fragment containing gene 2 inserted at the PstI site of pBR322 does not allow growth of P22 gene 2 amber mutants even though the number of wild-type recombinants is as high as in infection of the pP22-3 strain; J.Rutila, unpublished data.) The results of Table 3 therefore suggest that gene 2 as well as gene 1 is wholly contained in P22 EcoRI fragment $\mathrm{D}$. Gene 8 protein is not produced by either pP22-3 or pP22-4, as expected since gene 8 alleles are rescued from both fragments D and B (Tables 2 and 3). Gene 9 protein is not produced by pP22-201. The data of Table 3 suggest that pP22-4 may provide genes 5,7 , and 16 polypeptides, since significant numbers of amber mutant progeny are produced. The burst sizes of the 5,7 , or 16 amber progeny are low, perhaps because the plasmid does not produce the required large amounts of these phage structural proteins. However, we cannot exclude the possibility that the low levels of complementation observed are due to production of functional proteins 5,7 , or 16 by the small number of wild-type recombinant phage produced in the infection.

\section{DISCUSSION}

\section{Restriction Endonuclease Cleavage Site Map of Paz DNA}

Seven $E$ co RI cleavage sites and $14 \mathrm{Hind}$ III cleavage sites were mapped on P22 DNA by previous work in this laboratory (Jackson et al., 1978b; Deans and Jackson, 1979). These 21 sites define a map of the 
P22 chromosome having precisely located physical markers in most regions of the genome. In order to provide additional physical markers in some regions of special interest, we have determined the locations of cleavage sites for five additional restriction enzymes. Certain of these descrve comment.

Both SstI and SalI cleave P22 DNA at separate, single sites within the EcoRI B fragment, a segment about $20 \%$ the size of intact P22 which was not previously subdivided (Fig. 2). The SalI site was independently mapped by Weinstock and Botstein (Weinstock, 1977).

The SalI site proves useful in the analysis of P22 DNA packaging. We have proposed that $P 22$ initiates headful packaging of phage DNA at pac and that headfuls are packaged sequentially in a counterclockwise direction from that site (see Fig. 2). Eco RI cleavage of a linear P22 chromosome encapsulated at pac therefore yields a fragment having one end at $p a c$ and one end at EcoRI site 1 (coordinates 0.000-0.096 in Fig. 2). By this scheme, a Sall digest of P'2 DNA should contain an analogous fragment having one end at $p a c$ and one at the SalI site. The fact that such a fragment ( $S a l$ I B) is found and is present in low molar yield provides additional evidence for the position of pac and the counterclockwise direction of sequential packaging proposed earlier (Jackson et al., 1978a).

XhoI and SmaI each cleave P22 DNA close to pac and should be useful aids to further study of the phage DNA packaging initiation region. $B g l \mathrm{I}$ provides an additional cleavage site in EcoRI E, and so further subdivides the interesting regulatory region imm I (Botstein et al., 1975; Levine et al., 1975; Susskind and Botstein, 1975). Three restriction endonucleases which do not cleave P22 DNA have been identified: $X b a \mathrm{I}, B g l \mathrm{II}$, and $K p n \mathrm{I}$. Weinstock and Botstein (Weinstock, 1977) report $X b a \mathrm{I}, B g l \mathrm{II}$, $K p n \mathrm{I}$, and XhoI do not cleave P22 DNA. Although our results are in agreement for the first three enzymes, we find that XhoI cleaves P22 as shown in Fig. 1. Our results are summarized in the physical map of P22 DNA diagrammed in Fig. 2.
Restriction Fragments of P22 DNA Cloned in Plasmid Vector pBR322

The original physical map of EcoRI sites could be aligned approximately with the P22 genetic map, but the method by which some P22 early genes were assigned to individual restriction fragments (Jackson et al., 1978b) could not be extended to map late genes relative to particular cleavage sites. Our approach to placing P22 late genes on the P22 physical map was to clone individual P22 restriction fragments in a plasmid vector, and then to determine the P22 genetic markers present on the resulting recombinant plasmid by a marker rescue procedure. Fragments which together represent $60 \%$ of the P22 chromosome, including the entire late region, have been cloned in pBR322. Shotgun cloning of a P22 EcoRI digest yielded each of the $E c o$ RI fragments B, D, $\mathrm{E}, \mathrm{F}, \mathrm{G}$, and $\mathrm{H}$ as individual inserts in $\mathrm{pBR}$ 322. Cleavage of each recombinant plasmid with appropriate restriction endonucleases served to identify the orientation of each insert in the vector.

Two P22 EcoRI fragments, A and C, were not recovered as inserts in the plasmid from the shotgun cloning experiment. Attempts to clone EcoRI A from DNA preparations enriched for this fragment were also unsuccessful, although other P22 EcoRI fragments present as minor contaminants in this preparation were cloned in these experiments. This result is not surprising, as the P22 early promoters are located on $E$ co RI A (Botstein and Herskowitz, 1974; Jackson et al., 1978b), and expression of P22 genes on the fragment might interfere with plasmid replication or cell growth. The amount of phage repressor in the $\lambda i m m 21$ lysogenic host might be insufficient to repress multiple copies of the cloned fragment. Isolation of P22 Eco RI A clones may also be hindered by both the large size of the fragment and the reduced proportion of intact EcoRI A resulting from circular permutation.

One plasmid containing P22 EcoRI C was obtained from an experiment utilizing a DNA preparation in which the only DNA fragment having two EcoRI termini was 
fragment C. A single recombinant plasmid was isolated in this experiment. The low frequency at which P22 EcoRI C is recovered in a plasmid raises the possibility that this fragment may also encode functions deleterious to the host. If so, the single $E$ co RI C clone obtained may carry a mutation inactivating this function. All of the sequences of EcoRI C were readily cloned in three separate segments as fragments Bam HI B (pP22-250), EcoRI/Bam HI a (pP22-203), and Eco RI/Bam HI b (pP22201). Therefore, if a lethal function is expressed when $E$ coRI C is inserted at the EcoRI site of pBR322, it is not expressed from any of these three subsegments of EcoRI C.

The most surprising result of the shotgun cloning experiments was the recovery of P22 EcoRI D from a recombinant plasmid, since previous results predict that fragment D has only one EcoRI terminus and that the other end derives from the pac site (Jackson et al., 1979). However, EcoRI cleavage of chimeric plasmid pP22-3 (Fig. 3) generates a P22 fragment which comigrates with fragment $\mathrm{D}$ in an $E c o \mathrm{RI}$ digest of P22, and which has the expected restriction pattern when digested with $S m a I$ and $X h o I$. This result led us to consider whether some of the fragment $D$ formed in a P22 EcoRI digest might be generated by $E$ co RI-specific cleavage at a site very near pac. Since $D$ is found in low yield in a wild-type P22 Eco RI digest, the postulated EcoRI site near pac would have to be partially blocked. To test this model we have measured the molar yield of the packaging fragment $B$ observed in a SalI digest of wild type P22 DNA (Figs. 1 and 2). The yield of the pac-SalI site 1 fragment is in good agreement with the yield of the pac-EcoRI site 1 fragment (EcoRI D) (R. J. Deans, 1979). Therefore $E c o$ RI fragment D is not generated by $E c o$ RI - specific cleavage near pac. The cloning of P22 EcoRI D thus suggests that the pac terminus has one or more nucleotides in common with the EcoRI recognition sequence. Experiments to define the pac terminus further are in progress.

\section{Physical Gene Map of P22}

In order to place late genes on the P22 physical map, restriction fragments of wildtype P22 DNA were tested for ability to recombine with or to complement $\mathrm{P} 22 \mathrm{mu}$ tants defective in known late genes. When a $S$. typhimurium $\mathrm{Su}^{-}$strain carrying a chimeric plasmid is used as a host for plating a P22 amber mutant, an increase in plating efficiency on this host over the $\mathrm{Su}^{-}$control indicates the plasmid carries the wild type allele of the amber lesion (Table 2). Some P22 late genes were found to be expressed when carried on a plasmid insert, since $\mathrm{Su}$ strains containing the plasmid pP22-3 complemented P22 amber mutants defective in genes 1 or 2 (see Table 3). The plating efficiency of these P22 amber mutants on the complementing host $\left(1^{-}\right.$or $2^{-}$am on DB5289/pP22-3) was equal to the plating efficiency on the $\mathrm{Su}^{+}$host (Table 2). The ability of P22 amber mutants to plate on noncomplementing hosts (e.g., 8-am on DB5289/pP22-3 or DB5289/pP22-4; $9^{-}$am on DB5289/pP22-201) must be due to recombination, and the plating efficiencies are lower. It is not yet clear whether the high plating efficiencies and low burst sizes of P22 late mutants on the $\mathrm{Su}^{-}$strain carrying pP22-4 are due to complementation or recombination of cloned EcoRI B with the infecting amber mutant phage.

From the data of Tables 2 and 3, all P22 morphogenetic genes except gene 3 can be placed on the physical map of $E c o$ RI, HindIII, and Bam HI sites. Assignment of a mutational allele to a restriction fragment is based on the plating efficiency test (Table 2). Furthermore, complementation for a particular gene indicates the gene is intact on the cloned fragment. P22 EcoRI D therefore contains intact genes 1 and 2 as well as a small portion of the aminoterminal end of gene 8 . The coding capacity of fragment $\mathrm{D}$ is estimated as $1.5 \times 10^{5}$ daltons of protein, and the sums of the molecular weights of the gene 1 and 2 proteins is $1.6 \times 10^{5}$ (Botstein et al., 1973). Although most of the coding capacity of $E c o$ RI D has been accounted for, gene 3 protein $\left(0.1 \times 10^{5}\right.$ daltons $)$ which is en- 


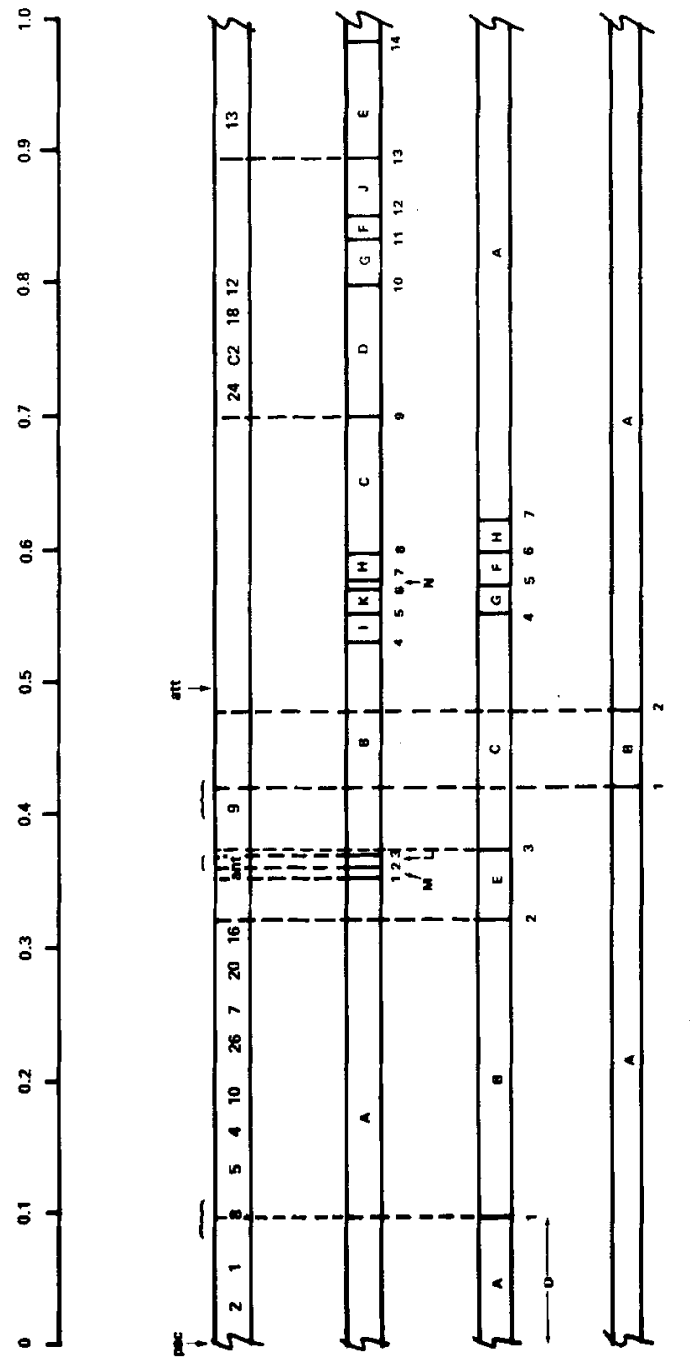

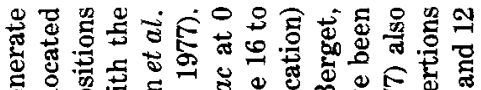

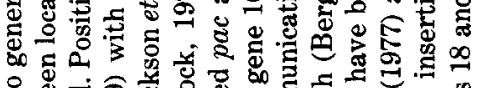

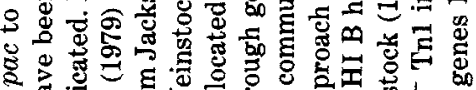

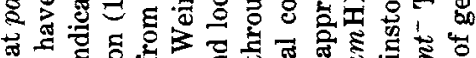
₹

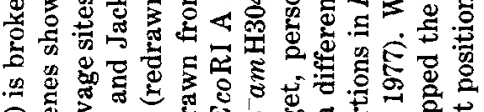
ล

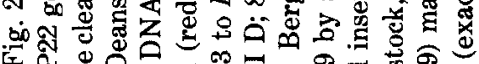

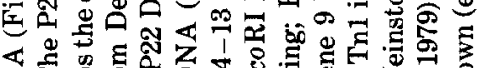

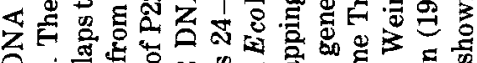

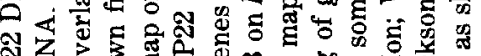

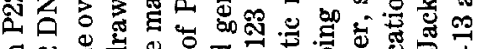

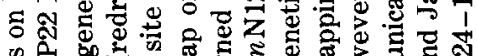
蛅

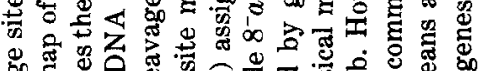

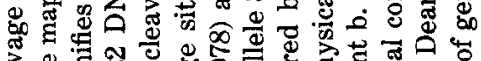

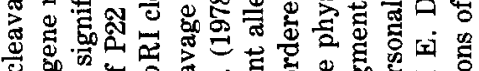
ए

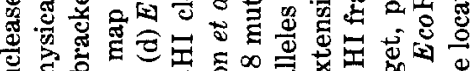

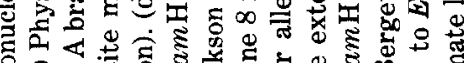

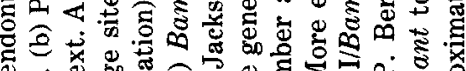
4

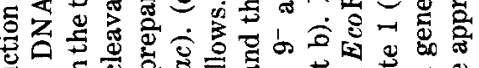

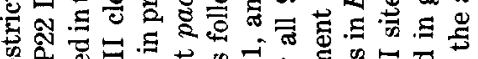

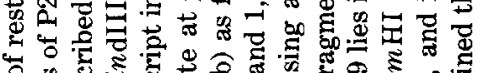

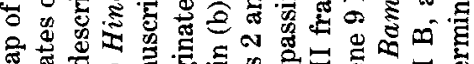

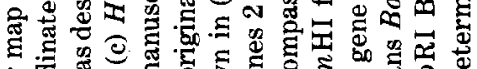
牙 踏

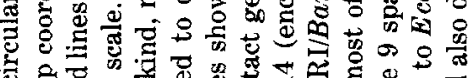

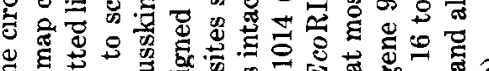

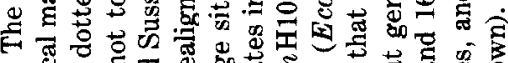

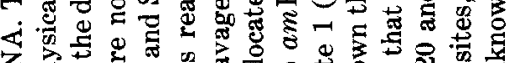

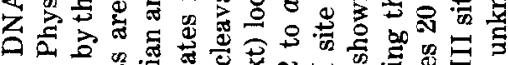

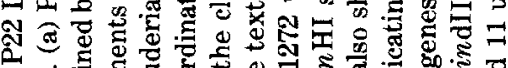

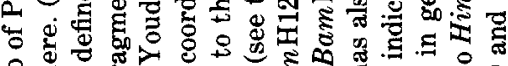

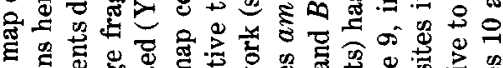

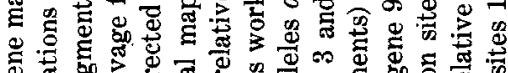

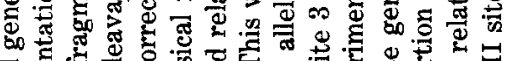

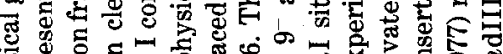

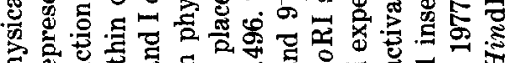

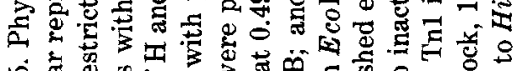
10

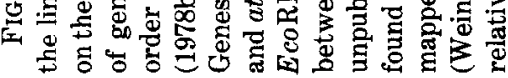


coded adjacent to gene 2 in the clockwise direction, could be accommodated. Gene 3 amber mutants do not plate with increased efficiency on $\mathrm{Su}^{-}$strains carrying $\mathrm{pP} 22-3$ (EcoRI D insert). However, any gene 3 sequences would be quite close to the junction of P22 and vector sequences, and the frequency of the recombination required to rescue the markers might be very low. The possibility that some gene 3 sequences might be on $E c o$ RI D cannot therefore be excluded.

The plating efficiency tests (Table 2) shows that EcoRI site 1 is located in gene 8 with most of gene 8 included on EcoRI fragment B. Gene 16 is on Eco RI B (Table 3), so that all genes which map between 8 and 16 (genes 5, 4, 10, 26, 7, 20; Poteete and King, 1977; Botstein et al., 1972) lie on Eco RI B. Weinstock and Botstein (Weinstock, 1977) have isolated Tn1 insertions in genes 20 and 16 and have shown that these insertions are located in $\mathrm{P} 22 E$ co RI B in agreement with our results.

EcoRI fragment B can code for about $3.4 \times 10^{5}$ daltons of protein, and the sum of the molecular weights of the proteins now known to be encoded on $B$ is $3.3 \times 10^{5}$. We have no information to indicate whether any sequences corresponding to sie $\mathrm{A}$, the next known gene counterclockwise from gene 16 (Susskind et al., 1974), are present on fragment $\mathrm{B}$, but sie $\mathrm{A}$ is not expressed by the plasmid clone since P22 plates on strains containing pP22-4.

Amber mutants in gene 9 have been placed in six ordered groups by deletion mapping ( $\mathrm{P}$. Berget, personal communication). A mutant from the most $\mathrm{N}$-terminal group (9-am H1272) and another mutant from the most C-terminal group (9-am $\mathrm{H} 1014)$ plate on an $\mathrm{Su}^{-}$strain carrying pP22-201. Therefore, both these alleles are located on $E c o$ RI/Bam HI fragment b (Table 2). The coding capacity of this fragment is about 6.7 $\times 10^{4}$ daltons, while the molecular weight of the gene 9 protein has been measured as $7.6 \times 10^{4}$ (Botstein et al., 1973). Thus gene 9 is unlikely to be wholly contained on EcoRI/BamHI b. Weinstock and Botstein (Weinstock, 1977) and Berget (personal communication) found that four of the $\operatorname{Tn} 1$ insertions which inactivate gene 9 are 10- cated in the Bam HI B fragment. Berget (unpublished results) has examined deletions extending from gene 20 to various sites in gene 9 , which localize most of gene 9 to $E c o$ RI/Bam HI fragment b, and a small segment of gene 9 to the Bam HI B fragment. These results, together with the data of Table 2, indicate that Bam HI site 1 lies in gene 9 , probably near the C-terminal end of the gene. The distance between the end of gene 9 and the att site is therefore less than $10 \%$ of the P22 genome, or a maximum of $4.2 \mathrm{~kb}$, about half the size of the analogous nonessential region of the $\lambda$ chromosome (Davidson and Szybalski, 1971).

The physical gene map of the P22 chromosome in Fig. 5 summarizes the positions of late genes relative to $E c o \mathrm{RI}, H i n \mathrm{dIII}$, and Bam HI sites. Comparison of this map with the recombination frequency map of P22 (Botstein et al., 1972) shows that distances in the late region of the recombination frequency map are distorted relative to the physical gene map. Genes 2 through 16 represent about $50 \%$ of the recombination frequency map, but only about $30 \%$ of the physical gene map (Fig. 5). Most of the expansion of the recombination frequency map occurs in genes $3,2,1,8$, and 5 . Since the molecular ends of mature P22 chromosomes fall in this portion of the map (Jackson et al., 1978), these genes are often located in a terminally redundant region of the mature chromosome. In a cross between phages mutant in this region, a significant proportion of the progeny will be heterozygotes which will score as wild-type recombinants in a standard cross, thus increasing the apparent recombination frequency.

Genetic recombination and complementation between cloned fragments of P22 DNA and phage mutants is a simple and powerful way to correlate the physical and genetic maps of the P22 chromosome. As demonstrated here for the case of gene 8 , this method can be used to map individual mutational alleles in a single gene relative to restriction sites, thereby generating a physical map of a single gene. Mutations in many P22 genes are available, and 33 restriction targets have already been mapped on P22 DNA (Fig. 2). The avail- 
ability of fragments cloned in pBR322, a vector for which the nucleotide sequence is known (Sutcliffe, 1978), should facilitate mapping many additional restriction sites in specific regions of P22. Furthermore, the plating efficiency test can be used as a simple method to detect and characterize additional plasmid clones. Thus the methods described here can be applied to facilitate P22 physical gene mapping to a high degree of resolution.

The availability of cloned fragments of P22 DNA will be important to a wide variety of future studies of P22. The use of strains carrying cloned fragments as permissive hosts should be a useful preliminary step in characterization and mapping of new mutants. Appropriate sets of overlapping cloned fragments can be used to quickly screen for mutations in a specific region. Plasmid bearing strains which complement P22 mutants can also serve as permissive hosts for isolation and propagation of classes of phage mutants not previously accessible, such as deletions in essential genes. Complementing strains will also be useful sources for phage protein isolation. Cloned fragments are currently serving in this laboratory as valuable sources of specific DNA segments for use as probes in nucleic acid hybridization experiments. Use of the clones and physical map information described here to generate transcriptional maps of P22, together with measurements of P22 gene function on cloned fragments, will be powerful approaches to studying control of $\mathrm{P} 22$ gene function.

\section{ACKNOWLEDGMENTS}

We thank David Botstein and Myron Levine who supplied the P22 mutant strains used here, and Peter Berget, Fred Winston and David Botstein who provided access to unpublished data. This work was supported by Grant AI-12369 from the National Institutes of Health. R.J.D. was supported in part by Institutional Research Grant $1 \mathrm{~N}-40 \mathrm{Q}$ to the University of Michigan from the American Cancer Society. R.L.C. was supported by Training Grant T32-GM-07544 from the National Institutes of Health.

\section{REFERENCES}

Bolivar, R., Rodriguez, R. L., Greene, P. J., Betlach, M. C., HeYNeKer, H. L., and Boyer, H. W. (1979). Construction and characterization of new cloning vehicles. II. A multipurpose cloning system. Gene 2, 95-113.

Botstein, D., Chan, R. K., and Waddell, C. H. (1972). Genetics of bacteriophage P22. II. Gene order and gene function. Virology 49, 268-282.

Botstein, D., and Herskowitz, I. (1974). Properties of hybrids between Salmonella phage P22 and coliphage $\lambda$. Nature (London) 251, 584-589.

Botstein, D., LEW, K. K., JARVIK, V., and SWANsoN, C. A., JR. (1975), Role of antirepressor in the bipartite control of repression and immunity by bacteriophage P22. J. Mol. Biol. 91, 439-462.

Botstein, D., WADDELL, C. H., and KING, J. (1973). Mechanism of head assembly and DNA encapsulation in Salmonella phage P22. I. Genes, proteins, structures and DNA maturation. J. Mol. Biol. 80 . 669-695.

Cameron, J. R., Panasenko, S. M., Lehman, I. R., and Davis, R. W. (1975). Proc. Nat. Acad. Sci. USA 72, 3416-3420.

Campbell, J. L., Richardson, C. C., and Studier, F. W. (1978). Genetic recombination and complementation between bacteriophage $\mathrm{T} 7$ and cloned fragments of T7 DNA. Proc. Nat. Acad. Sci. USA 75, 2276-2280.

Clewell, D. B. (1972). Nature of ColE1 plasmid replication in the presence of chloramphenicol. J. Bacteriol. 110, 667-676.

Davis, R. W., Simon, M., and Davidson, N. (1971). Electron microscope heteroduplex methods for mapping regions of base sequence homology in nucleic acids. In "Methods in Enzymology" (L. Grossman and K. Moldave, eds.), vol. 21, pp. 413-428. Academic Press, New York.

Davidson, N. and Szybalski, W. (1971). Physical and chemical characteristics of lambda DNA. In "The Bacteriophage Lambda" (A. D. Hershey, ed.), pp. 45-82. Cold Spring Harbor Press, Cold Spring Harbor, N. Y.

DEANS, R. J. (1979). "Physical Map of Phage P22: Generation and Characterization of Specific Fragments of the P22 Chromosome." Ph.D. thesis, The University of Michigan.

DEANS, R. J., and JACKson, E. N. (1979). Restriction endonuclease HindIII cleavage site map of bacteriophage P22. Virology 95, 359-372.

DeLeys, R. J., and JACKsoN, D. A. (1976). Electrophoretic analysis of covalently closed SV40 DNA: Boltzman distribution of DNA species. Nucleic Acids Res. 3, 641-652.

DenhardT, D. T. (1966). A membrane-filter technique for the detection of complementary DNA. Biochem. Biophys. Res. Commun. 23, 641-646.

Fiers, W., Contreras, R., Haegeman, A., Rogiers, R., VANDE VOORde, A., VAN HeUVerSwyN, H., VAN Herreweghe, J., Volckaert, A., and YSEBAERT, M. (1978). Complete nucleotide sequence of SV40 DNA. Nature (London) 273, 113-120. 
GRunstein, M., and Hogness, D. S. (1975). Colony hybridization: A method for the isolation of cloned DNAs that contain a specific gene. Proc. Nat. Acad. Sci. USA 72, 3961-3965.

JACKSON, E. N., JACKSON, D. A., and DEANS, R. J. (1978a). EcoRI analysis of bacteriophage P22 DNA packaging. J. Mol. Biol. 118, 365-388.

JACKSON, E. N., Miller, H. I., and ADAMS, M. L. (1978b). EcoRI restriction endonuclease cleavage site map of bacteriophage P22 DNA. J. Mol. Biol. 118, 347-363.

KInG, J., HaLl, C., and CaSJens, S. (1978). Control of the synthesis of phage P22 seaffolding protein is coupled to capsid assembly. Cell 15, 551-560.

LederberG, E. M., and Cohen, S. N. (1974). Transformation of $S$. typhimurium by plasmid deoxyribonucleic acid. J. Bacteriol. 119, 1072-1074.

Levine, M., Truesdell, S., Ramakrishnan, T., and BRoNSON, M. J. (1975). Dual control of lysogeny by bacteriophage P22: An antirepressor locus and its controlling elements. J. Mol. Biol. 91, 421-438.

MILleR, J. H. (1972). Experiments in Molecular Genetics. Cold Spring Harbor Press, Cold Spring Harbor, N. Y.

Murray, N. E., and MUrRay, K. (1974). Manipulation of restriction targets in phage $\lambda$ to form receptor chromosomes for DNA fragments. Nature (London) 251, 476-481.

Poteete, A. R., and King, J. (1977). Functions of two new genes in Salmonella phage P22 assembly. Virology 76, 725-739.

Rigby, P. W., DieckmanN, M., Rhodes, C., and BERG, P. (1977). Labelling DNA to high specific activity in vitro by nick translation with DNA polymerase I. J. Mol. Biol. 113, 237-251.
SOUTHERn, E. M. (1975). Detection of specific sequences among DNA fragments separated by gel electrophoresis. J. Mol. Biol. 98, 503-517.

Susskind, M. M., and Botstein, D. (1975). Mechanism of action of Salmonella phage P22 antirepressor. J. Mol. Biol. 98, 413-424.

Susskind, M. M., Botstein, D., and Wright, A. (1974). Superinfection exclusion by P22 prophage in lysogens of Salmonella typhimurium. III. Failure of superinfecting phage DNA to enter sie $\mathrm{A}^{+}$lysogens. Virology 62, 350-366.

SUTCLIFFE, J. A. (1978). pBR322 restriction map derived from the DNA sequence: Accurate size markers up to 4361 nucleotide pairs. Nucleic Acids Res. 5, 2721-2728.

Thomas, M., Cameron, J. R., and Davis, R. W. (1974). Viable molecular hybrids of bacteriophage $\lambda$ and eukaryotic DNA. Proc. Nat. Acad. Sci. USA $71,4579-4583$.

Thomas, M., and Davis, R. W. (1975). Studies on the cleavage of bacteriophage lambda DNA with Eco RI restriction endonuclease. J. Mol. Biol. 91, 315-328.

Tye, B. K., Huberman, J. A., and Botstein, D. (1974). Non-random circular permutation of phage P22 DNA. J. Mol. Biol. 85, 501-532.

Ullrich, A., Shine, J., Chirgwin, J., Pictet, R., Tischer, E., RUTTER, W. J., and Goodman, H. M. (1977). Rat insulin genes: Construction of plasmids containing the coding sequences. Science 196, 1313-1319.

Weinstock, G. M. (1977). "Genetic and Physical Studies of Bacteriophage P22 Genomes Containing Translocatable Drug Resistance Elements." Ph.D. thesis, Massachusetts Institute of Technology. 